\title{
ANALISA KUAT TEKAN BETON DENGAN MENGGUNAKAN SIKA CONCRETE REFAIR MORTAR DAN TEMPURUNG KELAPA PADA CAMPURAN BETON K 300
}

\author{
Asrullah \\ Dosen Tetap Program Studi Teknik Sipil Fakultas Teknik Universitas Palembang \\ email : asrull66@yahoo.co.id
}

\begin{abstract}
Abstrak
Tempurung kelapa merupakan limbah dari pabrik kopra dan pasar tradisional. Pemanfaatan limbah dapat mengurangi pencemaran lingkungan. Penambahan tempurung kelapa dalam campuran beton merupakan salah satu cara pemanfatan limbah. Sika Concrete Refair Mortar berpungsi sebagai komponen semen grouting untuk memperbaiki beton yang keropos dan juga untuk pengisi celah atau lubang-lubang seperti pada kolom baja, angkur baut dan sebaginya. Dalam penelitian ini peneliti mencoba menggunakan Sika Concrete Refair Mortar dan limbah tempurung kelapa dalam campuran beton. Metode rancangan campuran beton digunakan adalah SNI 03-2834-2000, sedangkan dalam pengujian kuat tekan digunakan metode SNI 03-1974-1990. Mutu beton yang digunakan adalah K 300 dengan benda uji kubus berukuran $15 \times 15 \times 15 \mathrm{~cm}$. Dalam penelitian ini variasi penambahan sika concrete refair mortar sebesar 2,5\%, 5\%, 7,5 dari berat semen dan tempurung kelapa sebesar 2,5\%, $5 \%$ dan 7,5\% dari berat agregat kasar. Dari hasil pengujian maka dapat disimpulkan bahwa kuat beton beton normal sebesar $302,50 \mathrm{~kg} / \mathrm{cm}^{2}$, kuat tekan terbesar dari penambahan Sika Concrete Refair Mortar terjadi pada penambahan Sika Concrete Refair Mortar 5\% dengan nilai kuat tekan 311,89 $\mathrm{kg} / \mathrm{cm} 2$. Kuat tekan beton dengan tempurung kelapa terbesar pada penambahan tempurung kelapa 2,5\% yaitu $267,87 \mathrm{~kg} / \mathrm{cm}^{2}$, sedangkan untuk kuat tekan terbesar penambahan Sika Concrete Refair Mortar dan tempurung kelapa sebesar $5 \%$ yaitu $240,85 \mathrm{~kg} / \mathrm{cm}^{2}$.
\end{abstract}

Keywords: Kuat Tekan, Sika Concrete Refair Mortar, Tempurung Kelapa, K 300

\section{LATAR BELAKANG}

Tanaman kelapa merupakan tanaman yang banyak dijumpai di seluruh pelosok Nusantara dan hasilnya sangat melimpah. Daging dari buah kelapa banyak dimanfaatkan untuk bahan pembuatan minyak dan untuk bahan tambahan makanan sedangkan tempurungnya dibuang begitu saja dan menjadi limbah pada lingkungan. Sampai saat ini pemanfaatan limbah berupa tempurung kelapa masih terbatas pada industri-industri mebel dan kerajinan rumah tangga dan belum diolah menjadi produk teknologi. Untuk itu dilakukanlahinovasi-inovasi bahan pencampuran beton untuk diuji coba agar bahan penyusunnya menjadi lebih ekonomis dengan mengganti bahan tersebut dengan bahan yang lainnya termasuk dengan pemanfaatan limbah yang ada disekitar kita dan hal teresbut dapat memberikan alternatif untuk pemanfaan limbah-limbah yang tidak termanfaatkan secara optimal.

Beton merupakan bagian dari konstruksi yang mempunyai peranan penting dalam pembangunan. Beton adalah campuran semen, agregat halus (pasir) dan agregat kasar (kerikil/split) serta ditambahkan bahan tambahan yang bervariasi [1]

Sika Concrete Refair Mortar berpungsi sebagai komponen semen grouting.untuk memperbaiki beton yang keropos dan juga untuk pengisi celah atau lubang-lubang seperti pada kolom baja,angkur baut dan sebaginya. Adapun keunggulannya adalah siap pakai dan mudah di aplikasikasikan, tidak susut, mudah mengalir, kekentalan bisa di atur sesuai konsumsi air, dan kekuatan mekanis tinggi [15].

Penelitian yang pernah dilakukan dengan menggunakan Sika Concrete Refair 
Mortar sebagai pengganti semen pada pengujian kuat K 300, Asrullah 2018, hasil penelitiannya menunjukkan bahwa terjadi fluktuasi nilai kuat tekan. Kuat tekan yang terbesar terjadi pada kondisi penggantian semen dengan Sika Concrete Refair Mortar sebesar $5 \%$ yaitu sebesar $311,89 \mathrm{~kg} / \mathrm{cm}^{2}$. Semakin besar penambahan Sika Concrete Refair Mortar lebih dari 5\%, maka nilai kuat tekan semakin turun. [2]. Penelitian yang dilakukan oleh Jacky dkk, 2018 menyimpulkan bahwa kuat tekan beton dengan pecahan tempurung kelapa menurunkan nilai kuat tekan beton. Kuat tekan dengan pecahan tempurung kelapa tertinggi pada kadar 4\% sebesar 27,98 Mpa dan menurunkan nilai kuat tekan beton sebesar 24,99\% dari kuat tekan beton normal [3]. Penelitian yang dilakukan oleh Fredy $d k k$, 2017, mengatakan bahwa campuran tempurung kelapa dalam beton dapat menurunkan nilai kuat tekan beton secara signifikan hampir 50\% [4]

\section{TINJAUAN PUSTAKA}

\subsection{Material Pembentukan Beton}

Beton yang digunakan sebagai struktur sebagai struktur dalam konstruksi teknik sipil dapat dimanfaatkan untuk banyak hal seperti untuk bangunan pondasi, kolom, balok, pelat lantai. Dalam teknik sipil hidro, beton yang digunakan untuk bangunan air seperti bendungan, saluran dan drainase. Beton merupakan fungsi dari bahan penyusun yang terdiri bahan semen hidrolik (Porlantd Sement), agregat kasar, agregat halus, air, dan bahan tambah (admixture atau additive) [6]

\subsection{Tempurung Kelapa}

Tempurung kelapa merupakan bagian dari buah kelapa yang masih belum banyak dimanfaatkan dibandingkan dengan bagian buah kelapa lainnya, meskipun sebagian kecilnya sudah diolah menjadi tepung kelapa dan arang. Berat dan tebal tempurung kelapa ditentukan oleh jenis tanaman kelapa. Berat tempurung sekitar 15-19\% bobot total buah kelapa dengan ketebalan 3-5 mm. Tempurung kelapa termasuk golongan kayu keras, secara kimiawi memiliki komposisi kimiawi yang hampir mirip dengan kayu yaitu tersusun dari lignin $36,51 \%$, selulosa $33,61 \%$, semiselulosa $29,27 \%[5]$.

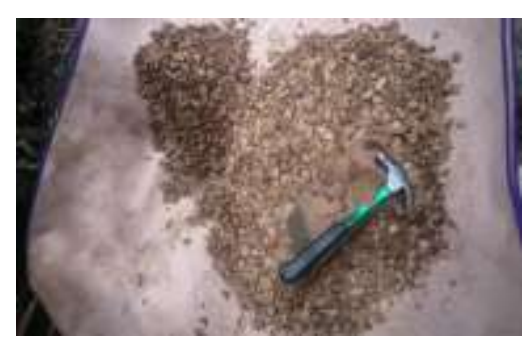

Gambar 1. Tempurung Kelapa

\subsection{Sika Concrete Refair Mortar}

Fungsi Sika Concrete Refair Mortar Digunakan untuk memperbaiki beton yang kropos dan juga untuk pwngisi celah atau lubang-lubang seperti padakolom baja,angkur baut, dsb. Keunggulan dari Sika Concrete Refair Mortar Siap pakai dan mudah diaplikasikan, tidak susut, mudah mengalir. Kekentalan bisa di atur sesuai kekentalan air dan mempunyai kekuatan mekanis tinggi [15]

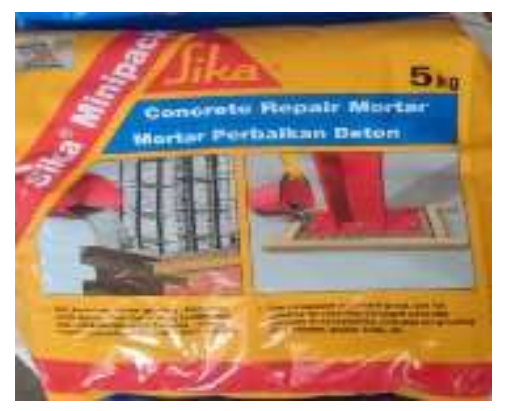

\section{Gambar 2. Sika Concrete Refair Mortar}

\subsection{Bahan Tambahan}

Bahan tambah (admixture) adalah suatu bahan berupa bubuk atau cairan, yang ditambahkan ke dalam campuran adukan beton selama pengadukan, dengan tujuan untuk mengubah sifat adukan atau betonnya. Berdasarkan ACI (American Concrete Institute), bahan tambah adalah material selain air, agregat dan semen hidrolik yang dicampurkan dalam beton atau sika yang ditambahkan sebelum atau selama pengadukan berlangsung. Penambahan bahan tambah dalam sebuah campuran beton atau sika tidak mengubah komposisi yang besar dari bahan lainnya, karena penggunaan bahan tambah ini cendurung merupakan pengganti atau susbtitusi dari dalam campuran beton itu 
sendiri. Karena tujuannya memperbaiki atau mengubah sifat dan karekteristik tertentu dari beton itu atau sika yang akan dihasilkan, maka kecenderungan perubahan komposisi dalam berat volume tidak terasa secara langsung di bandingkan dengan komposisi awal beton tanpa bahan tambah [16]

\subsection{Pengujian Slump}

Pengujian nilai Slump ialah salah satu cara untuk mengukur kecelakaan beton segar yang dipakai pula untuk memperkirakan tingkat kemudahan dalam pengerjaannya. dalam pelaksanaannya nilai Slump untuk berbagai pekerjaan pembetonan harus disesuaikan dengan syarat yang sesuai dengan pemakaiannya [7]. Nilai slump beton segar pada berbagai macam pemakaian disajikan pada tabel berikut ini [8]

\begin{tabular}{clcc}
\multicolumn{5}{c}{ Tabel 1 Nilai Slump Beton Segar } \\
\multicolumn{3}{c}{ Pada Berbagai Macam Pemakaian } \\
\hline No & \multicolumn{1}{c}{ Pemakaian } & $\begin{array}{l}\text { Maks } \\
(\mathrm{mm})\end{array}$ & $\begin{array}{c}\text { Min } \\
(\mathrm{mm})\end{array}$ \\
1 & $\begin{array}{l}\text { Dinding, Plat Pondasi, } \\
\text { dan pondasi telapak }\end{array}$ & 12,5 & 5 \\
2 & $\begin{array}{l}\text { Pondasi Telapak tidak } \\
\text { bertulang, kaison, dan }\end{array}$ & & 2,5 \\
& $\begin{array}{l}\text { struktur di bawah } \\
\text { tanah }\end{array}$ \\
3 & $\begin{array}{l}\text { Pelat, balok, kolom, } \\
\text { dan dinding }\end{array}$ & 15 & 7,5 \\
4 & $\begin{array}{l}\text { Pengerasan jalan } \\
\text { Pembetonan massal } \\
\text { (beton massa) }\end{array}$ & 7,5 & 5 \\
\hline
\end{tabular}

\subsection{Kuat Tekan (Compressive Strength)}

Pemeriksaan kuat tekan beton dilakukan untuk mengetahui secara pasti akan kekuatan tekan beton pada umur 28 hari yang sebenarnya apakah sesuai dengan yang direncanakan atau tidak. Pada mesin uji tekan benda diletakkan dan diberikan beban sampai benda runtuh, yaitu pada saat beban maksimum bekerja. Kuat tekan beton dapat dihitung dengan rumus [9]:

1. Rumus Kuat tekan beton

$$
\sigma b i=\frac{P}{A} \text {. }
$$

Dengan :

$$
\begin{aligned}
& \mathrm{P}=\text { Gaya maksimum dari mesin tekan, } \mathrm{kg} \\
& \mathrm{A}=\text { Luas penampang yang diberi } \\
& \quad \text { tekanan, } \mathrm{cm}^{2} \\
& \sigma b i=\text { Kuat tekan, } \mathrm{kg} / \mathrm{cm}^{2}
\end{aligned}
$$

2. Rumus Kuat tekan beton rata - rata

$$
\sigma b m=\frac{\sum \sigma b i}{N}
$$

Dengan :

$$
\sigma b m=\text { Kuat tekan beton rata }- \text { rata, } \mathrm{kg} / \mathrm{cm}^{2}
$$

$\Sigma \sigma b i=$ Kuat tekan, $\mathrm{kg} / \mathrm{cm}^{2}$

$N=$ Jumlah benda uji

3. Rumus deviasi standar

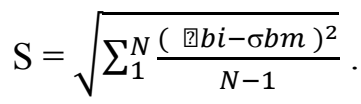

Dengan :

$$
\begin{aligned}
& \mathrm{S}=\text { Deviasi standar } \mathrm{kg} / \mathrm{cm}^{2} \\
& \sigma b m=\text { Kuat tekan beton rata-rata, } \mathrm{kg} / \mathrm{cm}^{2} \\
& \Sigma \sigma b i=\text { Kuat tekan, } \mathrm{kg} / \mathrm{cm}^{2} \\
& N=\text { Jumlah benda uji }
\end{aligned}
$$

4. Kuat tekan tekan beton karakeristik

$$
\sigma b k=\sigma b m-1,63 \times S
$$

Dengan :

$\sigma b m=$ Kuat tekan beton karakeristik, $\mathrm{kg} / \mathrm{cm}^{2}$ $\sigma b m=$ Kuat tekan beton rata $-\mathrm{rata}, \mathrm{kg} / \mathrm{cm}^{2}$

$1,64=$ Konstanta

$S=$ Deviasi standar $\mathrm{kg} / \mathrm{cm}^{2}$

\section{METHODOLOGI}

\section{3..1. Lokasi dan Bahan Penelitian}

Lokasi penelitian adalah di Laboratorium Bidang Pengujian, Peralatan dan Bahan Dinas Pekerjaan Umum Bina Marga dan Tata Ruang Provinsi Sumatera Selatan dan bahan yang digunakan dalam penelitian ini adalah :

1. Portland Semen adalah merek Semen Baturaja

2. Agregat kasar yang digunakan adalah batu pecah $19.00 \mathrm{~mm}$ dan $37.50 \mathrm{~mm}$ ex Merak

3. Agregat halus yang digunakan adalah pasir ex Tanjung Raja

4. Air PDAM Tirta Musi

5. Tempurung Kelapa dari Daerah Tanjung Lago Kabupaten Banyuasin

6. Bahan Tambahan yang digunakan adalah Sika Concrete Refair Mortar sebagai pengganti semen. 


\subsection{Ruang Lingkup Penelitian}

Ruang Lingkup Penelitian adalah :

1. Pemeriksaan karakteristik agregat halus dan kasar meliputi : pengujian berat jenis dan penyerapan air agregat kasar [10], pengujian berat jenis dan pengujian penyerapan air agregat halus [11], pengujian analisa saringan agregat halus dan kasar [12], pengujian kadar air agregat [13].

2. Pembuatan rencana campuran beton normal [14] terdiri dari :

- Beton Normal K 300 (kode BN)

- Beton dengan penambahan Sika Concrete Refair Mortar sebesar 2,5\%, $5 \%, 7,5 \%$ dari berat semen yang digunakan (kode BS)

- Beton dengan penambahan Tempurung kelapa sebesar 2,5\%, 5\%, 7,5\% dari berat agregat kasar yang digunakan (kode BT).

- Beton dengan penambahan Sika Concrete Refair Mortar sebesar 2,5\%, $5 \%, \quad 7,5 \%$ dari berat semen dan Tempurung kelapa sebesar 2,5\%, 5\% $7,5 \%$ dari berat agregat kasar. (kode BSBT)

3. Pengujian Slump beton [7]

4. Pengujian kuat tekan beton [9]

5. Mutu beton yang dibuat adalah beton K 300

6. Pengujian kuat tekan beton dilakukan pada umur beton 7,14,21 dan 28 hari.

\section{HASIL DAN PEMBAHASAN}

\subsection{Nilai Slump}

Pengujian nilai Slump dilakukan pada setiap campuran beton, hasil pengujian slump beton pada setiap campuran disajikan pada tabel 4

\section{Tabel 4 Nilai Slump Berbagai Variasi}

\begin{tabular}{clc}
\hline No & \multicolumn{1}{c}{ Kode Beton } & $\begin{array}{c}\text { Nilai Slump } \\
(\mathrm{mm})\end{array}$ \\
\hline 1 & BN & 82 \\
2 & BS 2,5\% & 78 \\
3 & BS 5\% & 75 \\
4 & BS 7,5\% & 72 \\
\hline
\end{tabular}

\begin{tabular}{cll}
\hline 5 & BT 2,5\% & 70 \\
6 & BT 5\% & 69 \\
7 & BT 7,5\% & 66 \\
8 & BSTK 2,5\% & 64 \\
9 & BSTK 5\% & 62 \\
10 & BSTK 7,5\% & 60 \\
\hline
\end{tabular}

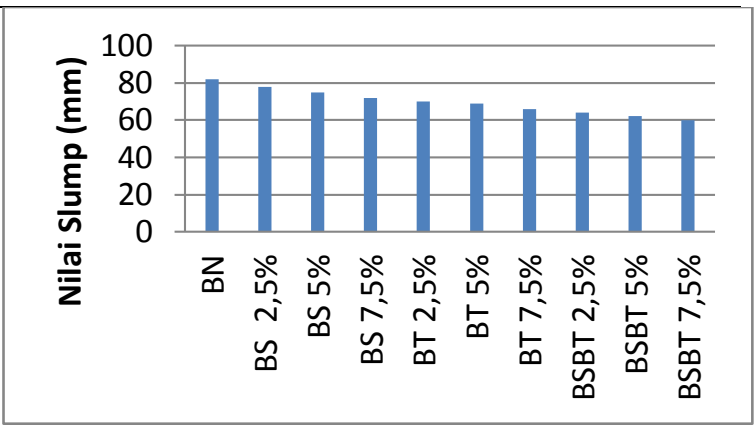

Gambar 3. Grafik Nilai Slump

Dari gambar 3, nilai slump menurun seiring dengan pertambahan persentase dari campuran beton baik penambahan persentase Sika Concrete Refair Mortar maupun penambahan persentasi tempurung kelapa. Kondisi ini disebabkan oleh banyaknya rongga beton akibat penambahan tempurung kelapa dan akibat pentyerapan dari Sika Concrete Refair Mortar

\subsection{Hasil Pengujian Kuat Tekan}

Hasil perhitungan pengujian kuat tekan beton karakteristik setiap campuran dan setelah dihitung disajikan dalam tabel 5 dan 6 .

Tabel 5. Kuat Tekan Beton Berdasarkan Umur Rencana

\begin{tabular}{lcccc}
\hline \multirow{2}{*}{$\begin{array}{c}\text { Kode } \\
\text { Beton }\end{array}$} & \multicolumn{4}{c}{ Umur Beton/Kuat Tekan $\left(\mathrm{kg} / \mathrm{cm}^{2}\right)$} \\
\cline { 2 - 5 } & 3 & 14 & 21 & 28 \\
\hline BN & 157,17 & 223,31 & 269,05 & 302,50 \\
BS 2,5\% & 160,30 & 244,07 & 287,48 & 296,73 \\
BS 5\% & 168,18 & 261,34 & 291,62 & 311,89 \\
BS 7,5\% & 140,41 & 204,96 & 240,25 & 269,13 \\
BT 2,5\% & 144,21 & 199,32 & 249,30 & 267,87 \\
BT 5\% & 124,03 & 178,36 & 212,82 & 244,07 \\
BT 7,5\% & 107,71 & 144,96 & 200,35 & 219,13 \\
BSBT2,5\% & 131,57 & 141,40 & 196,82 & 215,77 \\
BSBT 5\% & 141,66 & 224,86 & 251,16 & 240,85 \\
BSBT7,5\% & 130,42 & 200,72 & 229,51 & 231,47 \\
\hline
\end{tabular}

Tabel 6 Kuat Tekan Beton Umur 28 Hari

\begin{tabular}{lll}
\hline No & Kode Beton & Kuat Tekan \\
\hline
\end{tabular}




\begin{tabular}{clc}
\hline & & Beton $\left(\mathrm{kg} / \mathrm{cm}^{2}\right)$ \\
\hline 1 & BN & 302,50 \\
2 & BS 2,5\% & 296,73 \\
3 & BS 5\% & 311,89 \\
4 & BS 7,5\% & 269,13 \\
5 & BT 2,5\% & 267,87 \\
6 & BT 5\% & 244,07 \\
7 & BT 7,5\% & 219,13 \\
8 & BSBT 2,5\% & 215,77 \\
9 & BSBT 5\% & 240,85 \\
10 & BSBT 7,5\% & 231,47 \\
\hline
\end{tabular}

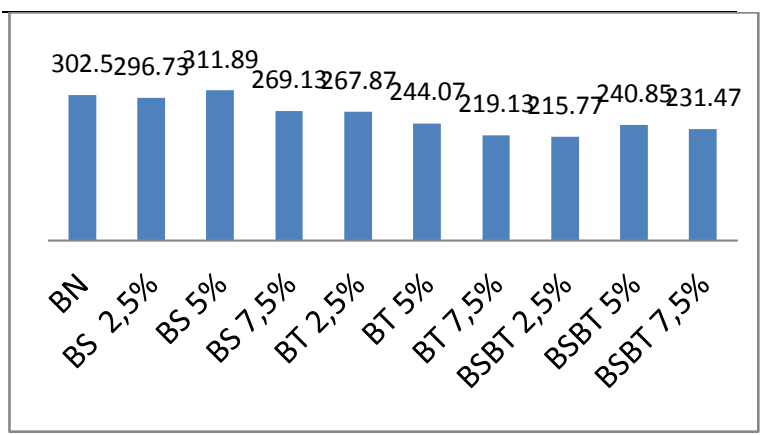

Gambar 4. Grafik Nilai Kuat Tekan Beton Semua Campuran Umur 28 Hari

Dari gambar 4, nilai kuat tekan beton normal (BN) sebesar $302,50 \mathrm{~kg} / \mathrm{cm}^{2}$ memenuhi target yang ditentukan. Beton dengan penambahan Sika Concrete Refair Mortar (BS) terjadi fluktuasi seiring dengan penambahan persentasi dalam campuran, kuat tekan terbesar terjadi pada penambahan $5 \%$, yaitu sebesar $311,89 \mathrm{~kg} / \mathrm{cm}^{2}$. Atau kenaikan sebesar 3,01\% dari beton $\mathrm{BN}$. Untuk beton campuran tempurung kelapa (BT) terjadi penurunan, semakin besar penambahan tempurung kelapa, maka semakin turun nilai kuat tekannya, kuat tekan terendah yaitu sebesar $219,13 \mathrm{~kg} / \mathrm{cm}^{2}$ dengan penambahan $7,5 \%$ atau penurunan sebesar 27,56\% dari beton normal (BN). Untuk beton dengan penambahan Sika Concrete Refair Mortar dan Penambahan Tempurung kelapa (BSBT) terjadi fluktuasi dan kuat tekan beton terbesar terjadi pada beton BSBT 5\% yaitu $240,85 \mathrm{~kg} / \mathrm{cm}^{2}$ atau penurunan sebesar 20,38\% dari kuat tekan beton BN.

\section{KESIMPULAN}

Dari hasil penelitian ini dapat disimpulkan sebagai berikut :
1. Kuat tekan beton Normal (BN) sebesar $302,50 \mathrm{~kg} / \mathrm{cm}^{2}$

2. Kuat tekan beton BS terbesar dengan penambahan Sika Concrete Refair Mortar 5\% dengan nilai kuat tekan $311,89 \mathrm{~kg} / \mathrm{cm}^{2}$.

3. Kuat tekan beton BT terbesar dengan penambahan tempurung kelapa 2,5\% dengan nilai kuat tekan $267,87 \mathrm{~kg} / \mathrm{cm}^{2}$.

4. Kuat tekan beton BSBT terbesar dengan penambahan Sika Concrete Refair Mortar dan tempurung kelapa $5 \%$ dengan nilai kuat tekan 240,85 $\mathrm{kg} / \mathrm{cm} 2$

\section{DAFTAR PUSTAKA}

[1] Ali Asroni, 2010, Balok dan Pelat Beton Beton Bertulang, Penerbit Graha Ilmu Yogyakarta, Cetakan Pertama.

[2] Asrullah 2018, Kuat Tekan Beton Dengan Menggunakan Sika Concrete Refair Mortar Sebagai Pengganti Semen Pada Campuran Beton K 300. Jurnal Teknik Sipil Volume 8, Nomor 1, November 2018 ISSN.2089-2950, pp 76-80

[3] Jacky, Debora Elnov, Anggi Debrinda Rama, Rizky Fernando, Rachmansyah, 2018. Pengaruh Pecahan Tempurung Kelapa Sebagai Pengganti Agregat Kasar Dalam Campuran Beton. Jurnal Teknik dan Ilmu Komputer Volume 07 Nomor 26, April-Juni 2018, pp 157-166

[4] Fredy Kurniawan, Nawir Rasidi, Wisnumurti, Andika Prawandha 2017, Pengaruh Penambahan Tempurung Kelapa Pada Beton. Konferensi Nasional Teknik Sipil dan Infrastruktur -I Jurusan Teknik Sipil Universitas jember, 30 Oktober 2017. pp S-143-S-152

[5] Dewi Pugersari, Achmad Syarief, Dwinita Laeasari 2013, Eksperimen Pengembangan Produk Fungsional Bernilai Komersial Berbahan Tempurung Kelapa Berusia Muda dengan Teknik Pelunakan, ITB J. Vis. Art\&Des. Volume 5 Nomor I, 2013. Pp 74-91. 
[6] Mulyono, Tri. 2003 Teknologi Beton Penerbit Andi Jakarta

[7] SNI 03-1972-1990 Metode Pengujian Slump Beton, Badan Standarisasi Nasional

[8] Peraturan Beton Bertulang Indonesia Tahun 1971 Dinas Pekrjaan Umum DPMB Bandung.

[9] SNI 03-1974-1990 Metode Pengujian Kuat Tekan Beton, Badan Standarisasi Nasional

[10] SNI 1969:2008 Cara Uji Berat Jenis dan Penyerapan Air Agregat Kasar, Badan Standarisasi Nasional

[11] SNI 03-1970-2008 Cara Uji Berat Jenis dan Penyerapan Air Agregat Halus, Badan Standarisasi Nasional

[12] SNI 03-1974-1990 Metode Pengujian Analisa Saringan Agregat Halus dan Kasar, Badan Standarisasi Nasional

[13] SNI 03-1971-1990 Metode Pengujian Kadar Air Agregat, Badan Standarisasi Nasional

[14] SNI 03-2834-2000 Tata Cara Pembuatan Rencana Campuran Beton, Normal, Badan Standarisasi Nasional

[15] http://idn.sika.com/in/group/tentangkami/katalog-sikaindonesia.html\#sthash.tvwDocHj.dpuf

[16] http://khedanta.wordpress.com/2012/06/11 /bahan-tamba-untuk-campuran-beton 